\title{
PENGEMBANGAN DAN VALIDASI INSTRUMEN ANALISIS BUKU TEMATIK-TERPADU PADA KURIKULUM 2013
}

\author{
'Alia Nur Husna Afandi', Kukuh Andri Aka' \\ alia.pgsd@gmail.com ${ }^{1}$, kukuh.andri@ unpkediri.ac.id ${ }^{2}$ \\ SDN Besowo 2, Kecamatan Kepung, Kabupaten Kediri ${ }^{1}$ \\ PGSD, FKIP, Universitas Nusantara PGRI Kediri ${ }^{2}$
}

\begin{abstract}
Abstrak: Tujuan penelitian pada artikel ini adalah untuk mengembangkan dan memvalidasi intrumen analisis buku tematik-terpadu yang mengacu pada kajian teori/variabel (1) karakteristik pembelajaran terpadu, (2) pendekatan saintifik, dan (3) prinsip buku ajar yang baik. Metode pada penelitian ini adalah; (1) mengkaji teori terkait pendekatan yang digunakan pada buku tematik-terpadu; (2) menyusun kisi-kisi intrumen yang terdiri dari variabel, sub variabel, dan indikator; (3) menyusun rubrik penskoran dan kriteria instrumen, (4) validasi kepada ahli; (5) perbaikan dan hasil akhir produk. Melalui kegiatan validasi ahli disimpulkan bahwa intrumen termasuk pada kategori yang valid dan dapat digunakan.
\end{abstract}

Kata kunci: instrumen, analisis, buku tematik-terpadu, kurikulum 2013

\section{DEVELOPMENT AND VALIDATION OF INSTRUMENTS INTEGRATED-THEMATIC BOOK ANALYSIS ON CURRICULUM 2013}

Abstract: The purpose of the research in this article is to develop and validate an integrated book analysis instrument that discusses theoretical studies (1) characteristics of integrated learning, (2) scientific approach, and (3) textbook principles. The method in this study is; (1) studies the related theoretical studies used in integrated thematic books; (2) develop instrument lines consisting of variables, sub variables, and indicators; (3) develope scoring rubrics and instrument criteria, (4) validation to experts; (5) product improvements and final results. Through validation the expert concludes that the categories are valid and can be used.

Keywords: instruments, analysis, thematic-integrated books, curriculum 2013

\section{PENDAHULUAN}

Kurikulum 2013 telah berlajalan selama lima tahun belakangan ini. Secara implementasi di lapangan, salah satu kunci sukses yang menentukan keberhasilan kurikulum 2013 adalah sumber belajar yang memadai, dan harus disadari, bahwa saat ini buku pelajaran menjadi sumber belajar yang sangat penting bagi siswa (Mulyasa, 2013). Buku 
'Alia, Kukuh, Pengembangan Instrumen Analisis Buku... pelajaran merupakan salah satu perangkat pembelajaran yang perlu diterapkan pada tiap pembelajaran di satuan pendidikan (Akbar, 2013). Buku pelajaran merupakan salah satu perangkat pembelajaran yang menjadi perhatian utama pada kurikulum 2013, hal itu didasari pada perbandingan penyusunan buku pelajaran kurikulum 2013 dengan KTSP.

Seperti yang diungkapkan oleh Sitepu (2012) acuan utama dalam menyusun buku pelajaran adalah kurikulum yang diberlakukan (kurikulum 2013), karena sasaran, tujuan, materi, dan metode penyajian materi terdapat pada kurikulum. Pada kurikulum 2013 peluang penyusunan buku pelajaran tidak dapat diperoleh sembarang orang, pemerintah telah menyiapkan tim khusus untuk menyusunnya.

Buku pelajaran kurikulum 2013 juga memiliki keunikan dari buku pelajaran sebelumnya, buku ini terdiri dari satu buku untuk guru dan satu buku untuk siswa dengan nama buku tematik terpadu kurikulum 2013. Saat ini pemerintah mengondisikan buku tematik terpadu kurikulum 2013 tersebut menjadi sumber wajib yang harus dipelajari siswa (Mulyasa, 2013). Kehadiran buku ini sangat penting dalam implementasi kurikulum 2013 karena pembelajaran seolah "tidak terarah" tanpa kehadiran buku tersebut.

Untuk melihat kajian teoritik mengenai kurikulum 2013 tidak dapat lepas dari KTSP, hal ini dikarenakan pengembangan kurikulum 2013 merupakan perbaikan dari evaluasi KTSP. Adapun perbedaan kurikulum sekolah dasar pada kurikulum 2013 dengan KTSP terletak pada pemaduan dari aspek-aspek yang masih terpisah-pisah pada KTSP, beberapa hal yang dipadukan antara lain memadukan kompetensi sikap, keterampilan, pengetahuan, dan memadukan kompetensi/materi dari berbagai mata pelajaran. Konsep pemaduan ini disebut dengan pembelajaran terpadu dengan model tematik.

Seperti yang disarikan menurut Kemendikbud (2013) pelaksanaan pembelajaran tematik terpadu menggunakan konsep pembelajaran terpadu. Tema digunakan sebagai pemersatu kegiatan pembelajaran secara holistik dengan memadukan beberapa mata pelajaran sekaligus dalam satu kali pembelajaran sehingga tidak terlihat pemisahan antar mata pelajaran pada suatu pembelajaran. Pembelajaran tematik terpadu juga dapat memberikan pengalaman yang bermakna bagi siswa, karena dalam memahami berbagai konsep yang mereka pelajari selalu melalui pengalaman langsung (otentik) dan menghubungkannya dengan konsep lain yang telah dikuasainya. Melalui pembelajaran tematik terpadu ini, keterlibatan siswa dalam belajar lebih diprioritaskan sehingga pembelajaran dapat lebih mengaktifkan siswa. 


\section{'Alia, Kukuh, Pengembangan Instrumen Analisis Buku...}

Mengacu pada perbedaan KTSP dengan kurikulum 2013, tidak akan lengkap jika hanya membahas implementasi pembelajaran tematik terpadu pada buku tematik terpadu kurikulum 2013. Pembahasan mengenai implementasi pendekatan saintifik diperlukan. Pendekatan saintifik (scientific) disebut juga sebagai pendekatan ilmiah, pada dasarnya pembelajaran dapat dipadankan dengan suatu proses ilmiah, karena itu kurikulum 2013 mengamanatkan esensi pendekatan saintifik dalam pembelajarannya (Sudio, 2013), artinya, buku guru dan buku siswa harus memuat konsep pendekatan saintifik. Pembelajaran saintifik memiliki ciri yaitu metode inkuiri, metode ini berbasis pada pencarian bukti dari beragam objek yang dipelajari harus dapat diobservasi secara empiris, dan terukur, karena itu, metode saintifik umumnya memuat rangkaian kegiatan atau aktivitas dari mengamati, menanya/mempertanyakan, menalar, mencipta, menyaji/mengomunikasikan (Akbar, 2013).

Selain hal di atas, penyusunan buku pelajaran kurikulum 2013 juga harus memenuhi prinsip-prinsip pengembangan buku ajar yang baik. Prinsip-prinsip tersebut antara lain (1) akurat, (2) sesuai, (3), komunikatif, (4) lengkap dan sistematis, (5) berorientasi terpusat pada siswa, (6) berpihak pada ideolegi bangsa dan negara, (7) kaidah bahasa yang benar, dan (8) terbaca (Akbar, 2013).

Melalui kajian-kajian di atas dan untuk memberikan sumbangsih pengetahuan tentang kontribusi perbaikan buku kurikulum 2013, maka melalui penelitian ini peneliti bertujuan untuk mengembangkan instrumen analisis buku tematik-terpadu yang melingkupi kajian/variable (1) karakteritik pembelajaran terpadu (holistik bermakna, otentik, dan aktif), (2) pendekatan saintifik (mengamati, menanya/mempertanyakan, menalar, mencipta, mengomunikasikan/menyaji), dan (3) prinsip buku ajar yang baik ( kelengkapan sajian dan relevansi, serta kaidah Bahasa).

\section{METODE}

Penelitian ini merupakan penelitian pengembangan dalam kegiatannya untuk menstandarisasi/validasi instrumen analisis analisis buku tematik-terpadu pada kurikulum 2013. Langkah-langkah pengembangannya adalah sebagai berikut, (1) mengkaji teori terkait pendekatan yang digunakan pada buku tematik-terpadu; (2) menyusun kisi-kisi intrumen yang terdiri dari variabel, sub variabel, dan indikator; (3) 
'Alia, Kukuh, Pengembangan Instrumen Analisis Buku... menyusun rubrik penskoran dan kriteria instrumen, (4) validasi kepada ahli; (5) perbaikan dan hasil akhir produk.

\section{HASIL DAN PEMBAHASAN}

\section{Kajian Teori pada Buku Tematik-Terpadu}

\section{Variabel Karakteristik Pembelajaran Terpadu}

Model pembelajaran terpadu berangkat dari pendekatan tematis sebagai acuan dasar bahan dan kegiatan pembelajaran. Tema yang dibuat dapat mengikat kegiatan pembelajaran, baik dalam mata pelajaran tertentu maupun antar mata pelajaran (Fogarty, 1991). Pembelajaran tematik-terpadu akan terjadi jika konsep-konsep dari berbagai mata pelajaran tersebut disatukan oleh tema (Tim Pengembang PGSD, 1996), dengan itu, siswa akan belajar sekaligus, baik proses dan isi berbagai mata pelajaran secara serempak.

Masih menurut Tim Pengembang PGSD (1996) pada buku "Pembelajaran Terpadu D-II PGSD dan S-2 Pendidikan Dasar", pembelajaran terpadu memiliki beberapa prisi, antara lain: (1) holistik, (2) bermakna, (3) otentik, dan (4) aktif. Artinya, pengembangan kurikulum 2013 perlu memperhatikan karakteristik pembelajaran terpadu tersebut. Hal ini akan berdampak pula pada buku pelajarannya, mengingat buku pelajaran merupakan penjabaran dari kurikulum (Sitepu, 2012).

Karakteristik tersebut secara lebih lengkap akan dijelaskan seperti di bawah ini.

\section{Holistik}

Aspek holistik pada pembelajaran muncul apabila pada pembelajaran tersebut terdapat suatu kajian yang menjadi pusat perhatian dan dipelajari serta dikaji dari beberapa muatan mata pelajaran sekaligus, tidak dari sudut pandang yang terkotak kotak. Pembelajaran ditujukan supaya siswa dapat memahami suatu fenomena dari segala sisi, hal ini akan membuat siswa menjadi lebih arif dan bijak di dalam menyikapi atau menghadapi kejadian yang ada di hadapannya (Tim Pengembang PGSD, 1996).

Dari uraian di atas, artinya buku pelajaran kurikulum 2013 sudah tidak disusun secara tiap mata pelajaran. Pembelajaran harus dikaji dari 2 muatan pelajaran atau lebih. Pemilihan subtema harus ada keterkaitan dengan tiap muatan antar mata pelajaran yang dikaji. 


\section{'Alia, Kukuh, Pengembangan Instrumen Analisis Buku...}

\section{Bermakna}

Menurut Ausubel (dalam Dahar, 1996) pembelajaran bermakna merupakan suatu proses mengaitkan informasi baru pada konsep-konsep yang relevan yang sudah ada pada pengetahuan seseorang. Sejalan dengan itu, pembelajaran bermakna menurut Tim Pengembang PGSD (1996) ialah pembelajaran yang dikaji secara holistik seperti yang diterangkan di atas, akan membentuk semacam jalinan antar skemata yang dimiliki siswa. Pembelajaran yang memadukan dari segala konsep yang diperoleh siswa dan keterkaitannya dengan konsep-konsep lain yang sudah dimilikinya akan menambah kebermaknaan konsep yang dipelajari (Tim Pengembang PGSD, 1996). Hal tersebut akan mengakibatkan kegiatan belajar yang lebih fungsional, siswa dapat mengaplikasikan pengetahuan yang telah dimilikinya untuk dipelajari lebih lanjut dalam pembelajaran, selain itu siswa dapat menerapkan perolehan belajarnya untuk memecahkan masalahmasalah yang nyata di dalam kehidupannya (Tim Pengembang PGSD, 1996).

Jadi, buku pelajaran yang mengadopsi aspek kebermaknaan pada pembelajaran terpadu harus memerhatikan relevansi kegiatan pembelajaran pada buku tersebut dengan adanya pengaitan informasi yang sudah dimiliki siswa dengan informasi baru yang akan dipelajari. Pembelajaran juga lebih bermakna jika sesuai dengan karakteristik siswa tersebut (operasiona kongrit untuk siswa kelas bawah dan operasional formal untuk kelas tinggi) (Piaget). Pada tahap ini anak mulai mampu berfikir logis (operasional) namun masih membutuhkan contoh-contoh yang nyata dalam pembelajaran agar siswa tersebut lebih memahami tentang materi yang diberikan (Hitipieuw, 2009). Selain hal di samping, tentunya pembelajaran akan lebih bermakna jika apa yang dipelajari siswa berguna untuk diterapkan dalam kehidupan sehari-harinya.

\section{Otentik}

Belajar secara otentik merupakan salah satu ciri pembelajaran terpadu. Di dalam belajarnya siswa perlu melakukan kegiatan secara langsung, hal ini karena pembelajaran terpadu memungkinkan siswa belajar secara langsung konsep dan prinsip yang ingin dipelajari (Tim Pengembang PGSD, 1996).

Dari pembelajaran secara otentik, siswa dapat memahami konsep dari hasil belajarnya sendiri, dari hasil interaksi fakta dan peristiwa bukan sekedar hasil pemberitahuan guru (Tim Pengembang PGSD, 1996). Dari hal tersebut, informasi dan pengetahuan yang diperoleh siswa dapat lebih otentik atau nyata, disini, guru lebih 
'Alia, Kukuh, Pengembangan Instrumen Analisis Buku...

bersifat sebagai fasilitator dan katalisator, sedangkan siswa sebagai aktor pencari informasi dan pengetahuannya. Melihat hal di atas, salah satu aspek agar buku pelajaran kurikulum 2013 dikatakan baik, perlu memunculkan kegiatan yang memungkinkan siswa mempelajari pengetahuan dan melibatkan pengalamannya secara nyata berdasarkan hasil belajarnya sendiri.

Menurut Smaldino (2011) dalam mempelajari secara nyata suatu pengetahuan atau pengalaman, pengalaman siswa dapat dibagi menjadi 4 tingkatan dari pengalaman abstrak menuju pengalaman konkret. Di mulai dari pengalaman mendengar dan membaca (tampilan video, visual, audio, teks), pengalaman observasi, simulasi dan permainan peran, sampai pada partisipasi (keterlibatan sebenarnya). Oleh karena itu, pengembangan instrumen penelitian ini untuk aspek otentik akan mengadaptasi dari tingkatan pengalaman Smaldino (2011).

\section{Aktif}

Aktif merujuk pada suatu keadaan di mana siswa terlibat secara aktif baik secara mental dan fisik dalam proses pembelajaran mulai dari proses perencanaan, pelaksanaan, dan evaluasi. Persoalan yang dihadapi ialah dalam Kurikulum 2013 buku sudah ditentukan (dipaket), silabus juga ditentukan oleh pemerintah pusat, maka negosiasi antara siswa dengan guru dalam menentukan proses perencanaan, pelaksanaan, dan evaluasi sulit untuk direalisir secara alamiah (Akbar, 2013). Karena perencanaan, pelaksanaan dan evaluasi sudah dipaket oleh pemerintah, maka aspek keaktifan akan difokuskan pada aktivitas mental dan fisik (melihat, mendengarkan, menulis, lisan, menggambar, gerak) siswa pada pelaksanaan pembelajaran.

Dalam pembelajaran banyak sekali aktivitas yang dilakukan siswa. Aktivitas siswa tidak cukup jika hanya mendengarkan dan menulis seperti yang lazim terjadi di sekolah-sekolah tradisional. Dari kompleksnya aktivitas yang dilakukan siswa, Paul B. Diedrich (dalam Sadirman, 2011) menggolongkan aktivitas yang dilakukan siswa selama pembelajaran menjadi 8 aktivitas yaitu aktivitas melihat (visual activities), aktivitas lisan (oral activities), aktivitas mendengarkan (listening activities), aktivitas menulis (writing activities), aktivitas menggambar (drawing activities), aktivitas gerak (motor activities), aktivitas mental (mental avtivities), dan aktivitas emosi (emotional activities). 


\section{'Alia, Kukuh, Pengembangan Instrumen Analisis Buku...}

a. Aktivitas Melihat

Aktivitas melihat merupakan kegiatan yang melibatkan indera penglihatan dalam pembelajaran. Karena pembelajaran pada kurikulum 2013 dipandu dengan buku pelajaran kurikulum 2013, maka buku tersebut perlu mendorong dan memunculkan aktivitas siswa seperti membaca, memerhatikan gambar, melihat video, demonstrasi, memerhatikan percobaan, memperhatikan pekerjaan orang lain, dan aktivitas lain yang melibatkan indera penglihatan secara aktif.

b. Aktivitas Lisan

Indikasi aktivitas lisan muncul pada buku pelajaran kurikulum 2013 bisa seperti munculnya aktivitas yang melibatkan siswa bertanya, memberikan saran, berpendapat, mengadakan wawancara, dan diskusi.

c. Aktivitas Mendengarkan

Aktivitas mendengarkan sudah pasti terjadi pada pembelajaran, karena aktivitas ini merupakan aktivitas dasar yang lazim dilakukan pada kegiatan belajar mengajar. Aktivitas mendengarkan tidak selalu kegiatan mendengarkan ceramah dari guru, melainkan bisa berupa mendengarkan musik, pidato, percakapan, dan diskusi dengan teman lainnya.

d. Aktivitas Menulis

Pada umumnya aktivitas ini menjadi kecenderungan pada pembelajaran. Aktivitas ini tidak selalu berupa kegiatan menulis atau mencatat informasi dari guru, melainkan bisa berupa membuat karangan maupun laporan.

e. Aktivitas Menggambar

Pada pembelajaran yang sudah-sudah, aktivitas ini cenderung hanya muncul pada pembelejaran kesenian, namun sebenarnya kegiatan menggambar bisa muncul dari mata pelajaran lainnya, seperti membuat grafik, diagram, peta, atau denah.

f. Aktivitas Gerak

Buku pelajaran kurikulum 2013 mengisyaratkan pembelajaran terpadu sebagai konsep yang dibawanya, artinya aspek keaktifan pada pembelajaran terpadu tidak boleh ditinggalkan, salah satu bentuk aspek keaktifan tersebut yaitu aktivitas gerak siswa, aktivitas ini sangat diperlukan, mengingat perubahan kurikulum bertujuan untuk membawa kegiatan belajar mengajar yang selama ini monoton dengan duduk di bangku kelas kemudian dirubah dengan kegiatan-kegiatan aktif selain duduk di kelas. Aktivitas 
'Alia, Kukuh, Pengembangan Instrumen Analisis Buku... gerak yang harus dimunculkan buku pelajaran kurikulum 2013 tersebut bisa berupa melakukan percobaan, membuat konstruksi, dan bermain peran.

\section{g. Aktivitas Mental}

Aktivitas mental terlihat jika buku pelajaran kurikulum 2013 memunculkan kegiatan-kegiatan yang mengindikasikan kegiatan siswa seperti menanggapi, mengingat, menganalisa, dan melihat hubungan. Kegiatan ini bisa dilihat pada tugas-tugas untuk siswa pada buku pelajaran tersebut.

h. Aktivitas Emosi

Contoh aktivitas ini adalah adanya semangat dan minat siswa, oleh karena itu aktivitas ini hanya dapat dilihat jika dilakukan observasi pembelajaran secara langsung, karena penelitian ini fokus pada analisis buku tanpa terlibat dalam pembelajaran maka aktivitas ini tidak dimuatkan pada instrumen.

Dari ketujuh aktivitas di atas (dengan meniadakan aktivitas emosi), aktivitas mendengar, menulis dan melihat akan dijadikan aktivitas minimal pada kajian ini. Aktivitas mendengar dan menulis dijadikan aktivitas minimal, karena aktivitas siswa tidak cukup hanya mendengarkan dan menulis. Aktivitas melihat dijadikan aktivitas minimal, karena penelitian ini berkaitan dengan buku teks yang tentunya aktivitas melihat (membaca buku) minimal telah dilakukan.

\section{Variabel Pendekatan Saintifik pada Kurikulum 2013}

Pendekatan saintifik merupakan icon dalam pembelajaran yang dituntut (diharapkan terjadi) pada Kurikulum 2013 (Akbar, 2013). Pendekatan saintifik (scientific) disebut juga sebagai pendekatan ilmiah, pada dasarnya pembelajaran dapat dipadankan dengan suatu proses ilmiah, karena itu kurikulum 2013 mengamanatkan esensi pendekatan saintifik dalam pembelajarannya (Sudio, 2013).

Untuk dapat disebut ilmiah atau saintifik, metode pencarian (method of inquiry) mutlak diperlukan, metode ini harus berbasis pada bukti-bukti dari objek yang dapat diobservasi, empiris, dan terukur dengan prinsip-prinsip penalaran yang spesifik (Sudio, 2013). Pendekatan saintifik adalah sebuah pola berfikir yang memiliki tahap dari adanya suatu masalah yang diperoleh melalui pengamatan, kemudian merumuskan masalah dengan mempertanyakan, kemudian melakukan penalaran dalam bentuk membangun hipotesis atau memberi jawaban yang bersifat tentatif (mungkin benar mungkin salah), 
'Alia, Kukuh, Pengembangan Instrumen Analisis Buku... kemudian mencoba atau menguji coba untuk mencipta, kemudian menyajikan/mengomunikasikan hasil uji ciptaannya (Akbar, 2013). Menurut (Akbar. 2013), pola pikir ilmiah tersebut bisa saja terjadi tidak harus urut, karena tidak semua persoalan dapat dipecahkan dengan pendekatan ilmiah. Fenomena rasional dapat didekati dengan pola berfikir ilmiah, tetapi untuk fenomena yang non-rasional (di luar kawasan rasio) tentu saja tidak selalu bisa di dekati secara ilmiah.

\section{Variabel Prinsip Buku Ajar yang Baik}

Salah satu kunci sukses yang menentukan keberhasilan implementasi kurikulum 2013 adalah sumber belajar yang memadai, dan sampai saat ini buku tematik terpadu merupakan sumber belajar yang sangat penting bagi siswa (Mulyasa, 2013). Buku pelajaran (saat ini, buku tematik terpadu kurikulum 2013) merupakan salah satu perangkat pembelajaran yang perlu diimplementasikan dalam praktik pembelajaran sehari-hari di satuan pendidikan (Akbar, 2013). Buku pelajaran merupakan salah satu perangkat pembelajaran yang menjadi perhatian utama pada kurikulum 2013, hal ini didasari pada perbandingan penyusunan buku pelajaran kurikulum 2013 dengan KTSP. Pada kurikulum 2013 peluang penyusunan buku pelajaran tidak dapat diperoleh sembarang orang, pemerintah telah menyiapkan tim khusus untuk menyusunnya.

Buku pelajaran kurikulum 2013 juga memiliki keunikan dari buku pelajaran sebelumnya, buku ini terdiri dari satu buku untuk guru dan satu buku untuk siswa dengan nama buku tematik terpadu kurikulum 2013. Saat ini, pemerintah mengondisikan buku pelajaran tersebut menjadi sumber wajib yang harus dipelajari siswa (Mulyasa, 2013).

Untuk lebih memfokuskan penelitian dan untuk memberikan kontribusi secara rinci, maka penelitian ini terbatas pada buku siswa. Di mana, buku siswa ini memuat kegiatan-kegiatan siswa dalam pembelajaran yang disusun tiap satu kali pembelajaran atau satu hari pertemuan.

Kehadiran buku siswa sangat penting dalam implementasi kurikulum 2013 karena pembelajaran seolah tidak akan berjalan tanpa kehadiran buku tersebut. Oleh karena itu, buku siswa perlu tidak hanya mengacu pada pembelajaran terpadu dan pendekatan saintifik, namun juga harus memenuhi prinsip-prinsip pengembangan buku ajar yang baik, yaitu (1) akurat, (2) sesuai, (3), komunikatif, (4) lengkap dan sistematis, (5) berorientasi terpusat pada siswa, (6) berpihak pada ideolegi bangsa dan negara, (7) kaidah bahasa yang benar, dan (8) terbaca (Akbar, 2013). 


\section{'Alia, Kukuh, Pengembangan Instrumen Analisis Buku...}

Dari kedelapan prinsip buku ajar yang baik di atas akan dilakukan penyesuaian untuk selanjutnya digunakan menyusun instrumen. Penyesuaian tersebut mempertimbangkan aspek kesamaan antara teori satu dengan yang lain, baik dalam satu rumpun teori buku ajar yang baik maupun lintas teori dengan teori pembelajaran terpadu dan saintifik. Misal, pada prinsip buku ajar yang baik, buku harus dapat mendorong rasa ingin tahu siswa. Rasa ingin tahu siswa dapat ditunjukkan dengan aktivitas bertanya siswa, sedangkan aktivitas bertanya sudah dibahas lebih mendalam pada teori pembelajaran saintifik. Prinsip-prinsip buku ajar yang baik tersebut akan diuraikan seperti di bawah ini yang disarikan dari Akbar (2013).

\section{Akurat (Akurasi)}

Aspek akurasi perlu diperhatikan untuk menghasilkan buku ajar yang baik (Zuchdi dalam Akbar, 2013). Keakuratan antara lain dapat dilihat dari aspek: kecermatan penyajian, benar memaparkan hasil penelitian, dan tidak salah mengutip pendapat pakar. Akurasi juga dapat dilihat dari kesesuaian teori pada buku dengan perkembangan teori mutakhir, dan pendekatan keilmuan yang bersangkutan.

Cara kerja prinsip ini ialah menyesuaiakan isi buku dengan menghadirkan sesuatu (hasil penelitian, teori pakar, dan teori muthakir) di luar buku pelajaran tersebut, tentu hal ini memerlukan waktu. Mengingat penelitian ini terbatas dengan waktu, maka prinsip ini tidak disertakan. Alasan lainnya yaitu buku yang akan dianalisis ditujukan untuk pembaca usia sekolah dasar, hal ini dapat diasumsikan kutipan-kutipan pakar dan pengertianpengertian yang bersifat teoritik tidak menjadi hal utama pada buku ini.

\section{Sesuai (Relevansi)}

Prinsip sesuai membahas tentang kesesuaian antara kompetensi yang harus dikuasai siswa dengan cakupan isi dan kedalaman pembahasan yang sesuai dengan kompetensi siswa (Akbar, 2013). Cakupan isi dalam buku ajar berupa adanya relevansi materi, tugas, contoh penjelasan, latihan dan soal, kelengkapan uraian dan ilustrasi sesuai dengan kompetensi yang akan dicapai.

Dari hal di atas, prinsip relevansi yang dikembangkan pada penelitian ini adalah (1) penyajian materi sesuai dengan tujuan pembelajaran yang harus dikuasai siswa dan (2) penyajian tugas/soal/latihan sesuai dengan tujuan pembelajaran yang harus dikuasai siswa. Dalam pengembangannya pada penelitian ini, prinsip sesuai hanya mampu dikembangkan menjadi 2 indikator, oleh karena itu prinsip ini perlu digabungkan dengan 
'Alia, Kukuh, Pengembangan Instrumen Analisis Buku... prinsip lain untuk memenuhi skala 4 tingkat indikator pada instrumen pedoman analisis. Prinsip lainnya yang digabungkan adalah prinsip kelengkapan sajian. Prinsip kelengkapan sajian dipilih untuk digabungkan dengan prinsip relevansi karena kajian kedua prinsip ini berkaitan dengan tujuan pembelajaran yang sama.

\section{Komunikatif}

Komunikatif artinya isi buku mudah dicerna pembaca, sistematis, jelas, dan tidak mengandung kesalahan bahasa (Zuchdi dalam Akbar, 2013). Agar komunikatif bahasa yang digunakan tidak perlu terlalu formal melainkan setengah lisan yakni seperti bahasa yang digunakan guru pada saat mengajar (Degeng dalam Akbar, 2013). Komunikatif dalam buku yang berupa tulisan dapat diamati dari kejelasannya yang mudah dicerna pembaca dengan kalimat yang tidak mengandung makna ganda, masuk akal dan logis. Pada instrumen, prinsip komunikatif tidak dilibatkan, karena prinsip ini sudah sama dengan prinsip struktur kalimat efektif pada aspek kaidah bahasa.

\section{Lengkap dan Sistematis}

Buku ajar yang memiliki kelengkapan sajian terdapat informasi kompetensi yang harus dikuasai siswa, informasi pentingnya penguasaan kompetensi bagi siswa, menyajikan daftar isi dan menyajikan daftar pustaka, sedangkan uraian yang sistematis yaitu mengikuti pola pikir dari sederhana ke kompleks atau dari lokal ke global (Akbar, 2013). Prinsip ini akan dikembangkan pada pedoman analisis dan digabungkan dengan prinsip relevansi. Indikator yang dikembangkan pada prinsip ini yaitu di dalam buku siswa harus (1) menyajikan kompetensi yang akan dikuasai siswa (KI, KD, indikator dan tujuan pembelajaran yang memuat kriteria ABCD) dan (2) menyajikan manfaat dan pentingnya penguasaan kompetensi bagi kehidupan siswa.

Tujuan pembelajaran harus ada pada buku siswa dan sesuai yang dinyatakan (Smaldino, 2011) yaitu tujuan pembelajaran akan mudah diikuti jika mencantumkan audience (audiensi) yaitu sasaran tujuan pembelajaran yakni siswa, behavior (perilaku) yaitu inti dari tujuan yang akan dimiliki siswa setelah pembelajaran dengan menggunakan kata kerja yang dapat diamati, condition (kondisi) yaitu kondisi atau suasana belajar untuk mencapai tujuan pembelajaran tersebut, dan degree (tingkat) yaitu pencapaian di mana perilaku dapat dinilai secara rinci dan terukur. Keempat kriteria ini sering disingkat dengan $\mathrm{ABCD}$. Hal ini untuk memotivasi siswa dalam belajar, juga sebagai ukuran 
'Alia, Kukuh, Pengembangan Instrumen Analisis Buku... menentukan keberhasilan pencapaian tujuan pembelajaran serta agar siswa memeroleh gambaran secara lengkap apa yang akan dipelajari.

Buku siswa perlu disajikan manfaat dan pentingnya penguasaan kompetensi agar siswa merasakan bahwa apa yang dipelajari tidak sia-sia dan ada kaitannya dengan kehidupan sehari-hari sehingga siswa akan mengamalkan apa yang dipelajari dalam kehidupannya. Penyajian manfaat ini dapat dituliskan di dalam buku secara informatif maupun penemuan mandiri siswa berupa tugas/bahan renungan.

Pada aspek kelengkapan sajian daftar isi dan daftar pustaka tidak dilibatkan pada penelitian kali ini, karena prinsip ini hanya dapat diukur jika prosedur analisis buku dilakukan pada satu buku bukan tiap pembelajaran. Misalnya, sajian daftar isi hanya ada pada halaman awal buku (tidak pada halaman awal tiap pembelajaran).

\section{Berorientasi pada Student Centered}

Buku ajar yang dikembangkan pada pendidikan dengan kurikulum yang cenderung konstruktivis perlu berorientasi pada student center yang harus mendorong rasa ingin tahu siswa, terjadinya interaksi antara siswa dengan sumber belajar, merangsang siswa membangun pengetahuan sendiri, menyemangati siswa belajar secara berkelompok dan menggiatkan siswa mengamalkan isi bacaan (Akbar, 2013:35). Prinsip ini diperlukan, namun pengembangannnya dalam instrumen tidak dilakukan. Hal ini, diasumsikan prinsip student center lebih dikonkretkan pada aspek aktif pada teori pembelajaran terpadu, yang mengisyaratkan berbagai aktivitas siswa yang harus muncul untuk dilakukan siswa, di samping itu prinsip student center juga telah muncul pada langkah-langkah pembelajaran saintifik yang melibatkan siswa melakukan pengamatan, menanya, menalar, mencipta dan mencoba sendiri sesuatu yang akan dipelajarinya.

\section{Berpihak pada Ideologi Bangsa dan Negara}

Buku ajar perlu mendukung ideologi bangsa dan negara, di Indonesia buku ajar perlu mendukung ideologi tentang ketakwaan kepada Tuhan yang Maha Esa, mendukung pertumbuhan nilai kemanusaiaan, mendukung kesadaran akan kemajemukan masyarakat, mendukung tumbuhnya rasa nasionalisme, mendukung tumbuhnya kesadaran hukum dan mendukung cara berpikir logis (Akbar, 2013). Setelah dilakukan kajian, prinsip ini tidak menjadi masalah urgent pada penelitian ini, di samping itu, pembahasan ini sangat luas dan memerlukan waktu. Oleh karena itu, prinsip ini tidak dikembangkan pada instrumen. 
'Alia, Kukuh, Pengembangan Instrumen Analisis Buku...

7. Kaidah Bahasa Benar

Prinsip kaidah bahasa benar muncul jika buku ajar yang ditulis menggunakan (1) ejaan, (2) istilah, dan (3) struktur kalimat yang tepat (Akbar, 2013). Kesalahan pemakaian kaidah bahasa dalam buku teks pelajaran harus dihindari karena siswa menggunakan buku itu sebagai sumber utama dan rujukan dalam belajar serta diasumsikan isi buku itu luput dari berbagai kesalahan termasuk kesalahan kaidah bahasa (Sitepu, 2012), dengan kata lain, buku tersebut dianggap sebagai acuan kaidah bahasa yang benar oleh siswa. Jika kesalahan tetap dibiarkan pada prinsip ini, dikawatirkan siswa menganggap kesalahan-kesalahan kaidah bahasa tersebut adalah hal yang benar.

Kaidah bahasa benar yang digunakan pada penelitian ini adalah (1) penggunaan ejaan yang tepat yaitu pemakaian huruf, penulisan kata, penulisan unsur serapan, dan pemakaian tanda baca sesuai dengan Pedoman Umum Ejaan Bahasa Indonesia (PUEBI) Permendikbud 50/2015. (2) Penggunaan istilah yang tepat yaitu penggunaan istilah yang sesuai dengan Kepmendiknas nomor 146/U/2004 tentang penyempurnaan pedoman umum pembentukan istilah. (3) Struktur kalimat yang tepat yaitu struktur kalimat yang efektif digunakan dengan memerhatikan struktur kalimat umum, struktur kalimat periodik, dan struktur kalimat paralel berupa kesejajaran bentuk dan kesejajaran makna (Putrayasa, 2007).

Dari uraian tersebut, peneliti mengembangkan tiga indikator pada instrumen, yaitu (1) penggunaan ejaan sesuai pedoman umum ejaan bahasa Indonesia yang disempurnakan, (2) penggunaan istilah sesuai penyempurnaan pedoman umum pembentukan istilah, (3) struktur kalimat yang efektif.

\section{Terbaca}

Buku ajar yang keterbacaannya tinggi mengandung panjang kalimat dan struktur kalimat sesuai pemahaman pembaca, panjang alineanya sesuai pemahaman pembaca (Akbar, 2013). Prinsip ini tidak menjadi masalah urgent pada penelitian ini, misalnya prinsip ini mengkaji berkaitan panjang kalimat, struktur kalimat, dan panjang alinea, padahal buku siswa yang akan diteliti adalah buku berbasis aktivitas, di dalamnya jarang terdapat kalimat yang panjang tentang materi, namun lebih mengarah pada kalimat perintah yang sederhana untuk memfokuskan kegiatan dan aktivitas siswa, di samping itu pembahasan ini sangat luas dan memerlukan waktu. Oleh karena itu, prinsip ini tidak dikembangkan pada instrumen. 


\section{‘Alia, Kukuh, Pengembangan Instrumen Analisis Buku...}

\section{Susunan Kisi-Kisi Instrumen Analisis Buku Tematik-Terpadu}

Berdasarkan kajian teoritik di atas, telah tersusun kis-kisi intrumen yang terdiri dari tiga variabel, 11 sub variabel, dan 11 indikator variabel yang ditabelkan pada tabel di bawah ini.

\section{Tabel 1. Kisi-Kisi Instrumen Angket Analisis Buku Tematik-Terpadu}

\begin{tabular}{|c|c|c|}
\hline Variabel & Sub Variabel & Indikator \\
\hline \multirow{4}{*}{$\begin{array}{l}\text { Karakteristik } \\
\text { pembelajaran } \\
\text { terpadu }\end{array}$} & 1. Holistik & $\begin{array}{l}\text { 1. Pembelajaran dikaji dari } 2 \text { muatan pelajaran atau lebih. } \\
\text { 2. Pemilihan subtema dapat mengaitkan tiap muatan } \\
\text { antar mata pelajaran yang dikaji. }\end{array}$ \\
\hline & 2. Bermakna & $\begin{array}{l}\text { 1. Adanya pengaitan informasi yang sudah dimiliki siswa } \\
\text { dengan informasi baru yang akan dipelajari } \\
\text { 2. Berguna bagi siswa untuk diterapkan dalam kehidupan } \\
\text { sehari-harinya. } \\
\text { 3. Sesuai dengan karakteristik tingkat berfikir siswa }\end{array}$ \\
\hline & 1. Otentik & $\begin{array}{l}\text { 1. Memungkinkan siswa memahami secara langsung } \\
\text { pengetahuan yang ingin dipelajari berdasarkan hasil } \\
\text { belajarnya sendiri dan terlibat nyata dalam } \\
\text { pembelajaran, bukan sekedar hasil pemberitahuan } \\
\text { informasi dari guru dan buku. }\end{array}$ \\
\hline & 4. Aktif & $\begin{array}{l}\text { 1. Pelibatan siswa secara aktif dalam proses } \\
\text { pembelajaran. }\end{array}$ \\
\hline \multirow{5}{*}{$\begin{array}{l}\text { Pendekatan } \\
\text { saintifik }\end{array}$} & 1. Mengamati & $\begin{array}{l}\text { 1. Terdapat kegiatan mengamati sesuatu secara cermat } \\
\text { (tanpa atau dengan alat). }\end{array}$ \\
\hline & $\begin{array}{l}\text { 2. Menanya- } \\
\text { Mempertanyakan }\end{array}$ & $\begin{array}{l}\text { Terdapat kegiatan mengajukan berbagai } \\
\text { pertanyaan/menanyakan beragam informasi yang } \\
\text { tidak/belum dipahami dari apa yang diamati atau } \\
\text { pertanyaan untuk mendapatkan informasi tambahan } \\
\text { tentang apa yang diamati(dimulai dari pertanyaan } \\
\text { faktual sampai ke pertanyaan yang bersifat hipotetis). }\end{array}$ \\
\hline & 3. Menalar & $\begin{array}{l}\text { 1. Melakukan eksperimen/membaca sumber lain selain } \\
\text { buku teks/mengamati } \\
\text { objek/kejadian/aktivitas/wawancara dengan } \\
\text { narasumber }\end{array}$ \\
\hline & 4. Mencipta & $\begin{array}{l}\text { 1. Mengolah hasil menalar dengan membuat sesuatu } \\
\text { (hipotesis, bentuk karya secara tertulis maupun media } \\
\text { lainnya). }\end{array}$ \\
\hline & $\begin{array}{l}\text { 5. Mengomunikasikan/ } \\
\text { Menyaji }\end{array}$ & $\begin{array}{l}\text { 1. Menyampaikan hasil pengamatan, kesimpulan } \\
\text { berdasarkan hasil analisis secara lisan, tertulis, atau } \\
\text { media lainnya. }\end{array}$ \\
\hline $\begin{array}{l}\text { Prinsip buku } \\
\text { ajar yang } \\
\text { baik }\end{array}$ & $\begin{array}{l}\text { 1. Kelengkapan Sajian } \\
\text { dan Relevansi }\end{array}$ & $\begin{array}{l}\text { 1. Menyajikan kompetensi yang akan dikuasai siswa (KI, } \\
\text { KD, indikator dan tujuan pembelajaran yang memuat } \\
\text { kriteria ABCD). } \\
\text { 2. Menyajikan manfaat dan pentingnya penguasaan } \\
\text { kompetensi bagi kehidupan siswa (secara informatif } \\
\text { maupun penemuan mandiri siswa berupa tugas). } \\
\text { 3. Penyajian semua materi sesuai dengan kompetensi } \\
\text { yang harus dikuasai siswa } \\
\text { 4. Penyajian semua (tugas/soal/latihan) sesuai dengan } \\
\text { kompetensi yang harus dikuasai siswa . }\end{array}$ \\
\hline
\end{tabular}


'Alia, Kukuh, Pengembangan Instrumen Analisis Buku...

\begin{tabular}{|c|l|l|}
\hline \hline Variabel & \multicolumn{1}{|c|}{ Sub Variabel } & \multicolumn{1}{c|}{ Indikator } \\
\hline & 2. Kaidah Bahasa & 1. Penggunaan ejaan \\
& & 2. Penggunaan istilah \\
& & 3. Struktur kalimat yang efektif. \\
\hline
\end{tabular}

Sumber: (Tim Pengembang PGSD, 1996:3-4), (Kemendikbud, 2013:12-14), (Akbar, 2013:14),

(Akbar, 2013:34-40).

\section{Susunan Cara Kerja Instrumen, Bentuk Rubrik Penskoran dan Kriteria Instrumen}

Produk instrument pada penelitian ini berupa angket yang terdiri dari empat skala

kesesuaian. Adapun tahap penggunaan instrument ini adalah sebagai berikut:

1. Menghitung kemunculan indikator yang ditemukan untuk setiap kategori pada setiap materi yang dianalisis dengan tanda cheklist $(\sqrt{ })$.

2. Menghitung persentase kemunculan indikator untuk setiap variabel pada buku yang dianalisis dengan rumus.

Persentase yang diperoleh $=\frac{\sum \text { skor yang muncul }}{\sum \text { skor keseluruhan }} \times 100 \%$

3. Untuk variabel karakteristik pembelajaran terpadu diukur menjadi 4 sub variabel (holistik, bermakna, otentik, dan aktif) keempat sub variabel tersebut akan dijumlahkan kemudian dibagi 4, untuk memperoleh nilai total variabel karakteristik pembelajaran terpadu.

4. Untuk variabel buku ajar yang baik diukur menjadi 2 sub variabel (kelengkapan sajian-relevansi dan kaidah bahasa) kedua sub variabel tersebut dijumlahkan kemudian dibagi 2 untuk memperoleh nilai total variabel prinsip buku ajar yang baik.

5. Menentukan kriteria kesesuaian secara deskripsi menggunakan tabel di bawah ini.

Tabel 2. Kriteria Tingkat Kesesuaian

\begin{tabular}{|l|l|l|}
\hline No & Kriteria Validitas & Tingkat Validitas \\
\hline 1 & $85,01 \%-100,00 \%$ & Sangat valid, atau dapat digunakan tanpa revisi \\
\hline 2 & $70,01 \%-85,00 \%$ & Cukup valid, atau dapat digunakan namun perlu direvisi kecil \\
\hline 3 & $50,01 \%-70,00 \%$ & Kurang valid, disarankan tidak dipergunakan karena perlu revisi besar \\
\hline 4 & $01,00 \%-50,00 \%$ & Tidak valid, atau tidak boleh dipergunakan \\
\hline
\end{tabular}
(Sumber : Akbar, 2013:41).

6. Mengungkapkan hasil analisis secara deskriptif pada tiap variabel

\section{Validasi Ahli}

Instrumen penelitian adalah alat untuk mengumpulkan data pada suatu penelitian. Sejalan dengan itu, Arikunto (2010: 203) mengemukakan, instrumen penelitian merupakan alat atau fasilitas yang digunakan oleh peneliti dalam mengumpulkan data 
'Alia, Kukuh, Pengembangan Instrumen Analisis Buku... agar memudahkan pekerjaannya dan hasilnya lebih baik. Instrumen yang digunakan pada penelitian ini berupa angket.

Untuk mendapatkan instrumen angket yang valid digunakan, maka akan dilakukan validasi. Validasi tersebut berupa validasi konstruksi. Cara kerja validasi konstruksi ialah menggunakan pendapat dari ahli (judgement expert) untuk memberikan keputusannya (dapat digunakan tanpa perbaikan, ada perbaikan, dan mungkin dirombak total) mengenai instrumen yang telah dikonstruksi berdasarkan pada kajian teori (Sugiyono, 2011:125). Kriteria ahli tersebut harus menguasai lingkup karakteristik pembelajaran terpadu, pendekatan saintifik, dan pengembangan bahan ajar. Validator tersebut adalah Dr. I Made Suardana, S.Pd., M.Pd. Fokus aspek yang divalidasi adalah kesesuaian intrumen dengan kajian terori yang dipakai, yaitu (1) Karakteristik pembelajaran terpadu, (2) Pendekatan saintifik, dan (3) Prinsip buku ajar yang baik. Adapun hasil validasi yang telah dilakukan menunjukkan pedoman analisis ini mencapai tingkat validitas $84,38 \%$ dan termasuk pada kriteria cukup valid, dan dapat digunakan dengan revisi kecil. Revisi pada instrumen beracu pada saran perbaikan validator yang menekankan untuk lebih menspesifikkan indikator instrumen.

\section{Perbaikan dan Hasil Akhir Instrumen}

Berdasarkan hasil validasi ahli dan beberapa perbaikan untuk lebih menspesifikkan beberapa indikator pada intrumen, maka asil akhir instrumen adalah sebagai berikut.

Angket Kesesuaian Buku Tematik Terpadu Kurikulum 2013 Variabel Karakteristik Pembelajaran Terpadu

1. Sub Variabel Karakteristik Holistik

Tabel 3. Angket Sub Variabel Holistik

\begin{tabular}{|c|c|c|c|c|c|c|c|}
\hline \multirow{2}{*}{ Tema } & Sub & Pembelajaran & \multicolumn{4}{|c|}{ Skor } & Keterangan \\
\cline { 4 - 8 } & Tema & ke- & 1 & 2 & 3 & 4 & \\
\hline & & & & & & & \\
\hline
\end{tabular}

Indikator karakteristik holistik:

- Skor 4 jika dalam 1 pembelajaran dikaji 3 muatan mata pelajaran atau lebih dan pemilihan subtema dapat mengaitkan tiap muatan mata pelajaran yang dikaji.

- Skor 3 jika dalam 1 pembelajaran dikaji 2 muatan mata pelajaran dan pemilihan pemilihan subtema dapat mengaitkan tiap muatan mata pelajaran yang dikaji. 
'Alia, Kukuh, Pengembangan Instrumen Analisis Buku...

- Skor 2 jika dalam 1 pembelajaran dikaji 3 muatan mata pelajaran atau lebih dan pemilihan subtema tidak dapat mengaitkan tiap muatan mata pelajaran yang dikaji.

- Skor 1 jika dalam 1 pembelajaran dikaji 2 muatan mata pelajaran dan pemilihan subtema tidak dapat mengaitkan tiap muatan mata pelajaran yang dikaji.

2. Sub Variabel Karakteristik Bermakna

Tabel 4. Angket Sub Variabel Bermakna

\begin{tabular}{|c|c|c|c|c|c|c|c|}
\hline \multirow{2}{*}{ Tema } & Sub & Pembelajaran & \multicolumn{4}{|c|}{ Skor } & Keterangan \\
\cline { 3 - 8 } & Tema & ke- & $\mathbf{1}$ & $\mathbf{2}$ & $\mathbf{3}$ & $\mathbf{4}$ & \\
\hline & & & & & & & \\
\hline
\end{tabular}

Indikator karakteristik bermakna:

- Skor 4 jika isi kegiatan dalam buku mendukung 3 bentuk kebermaknaan

- Skor 3 jika isi kegiatan dalam buku mendukung 2 bentuk kebermaknaan

- Skor 2 jika isi kegiatan dalam buku mendukung 1 bentuk kebermaknaan

- Skor 1 jika isi kegiatan dalam buku tidak mendukung kebermaknaan

Bentuk-bentuk kebermaknaan

- Adanya pengaitan informasi yang sudah dimiliki siswa dengan informasi baru yang akan dipelajari

- Berguna bagi siswa untuk diterapkan dalam kehidupan sehari-harinya

- Sesuai dengan karakteristik tingkat berfikir siswa

\section{Sub Variabel Karakteristik Otentik}

Tabel 5. Angket Sub Variabel Otentik

\begin{tabular}{|c|c|c|c|c|c|c|c|}
\hline \multirow{2}{*}{ Tema } & Sub & Pembelajaran & \multicolumn{4}{|c|}{ Skor } & Keterangan \\
\cline { 3 - 8 } & Tema & ke- & 1 & 2 & 3 & 4 & \\
\hline & & & & & & & \\
\hline
\end{tabular}

Indikator karakteristik otentik:

- Skor 4 jika kegiatan dalambuku memungkinkan keterlibatan siswa yang sebenarnya (partisipasi)

- Skor 3jika kegiatan dalam buku memungkinkan keterlibatan siswa hanya sampai pada simulasi dan permainan peran

- Skor 2 jika kegiatan dalam buku memungkinkan keterlibatan siswa hanya sampai pada demonstrasi (observasi) 
'Alia, Kukuh, Pengembangan Instrumen Analisis Buku...

- Skor 1 jika kegiatan dalam buku memungkinkan keterlibatan siswa hanya sampai pada mendengarkan dan membaca (baik tampilan video, visual, audio, dan teks).

4. Sub Variabel Karakteristik Aktif

Tabel 6. Angket Sub Variabel Aktif

\begin{tabular}{|c|c|c|c|c|c|c|c|}
\hline \multirow{2}{*}{ Tema } & Sub & Pembelajaran & \multicolumn{4}{|c|}{ Skor } & Keterangan \\
\cline { 4 - 8 } & Tema & ke- & $\mathbf{1}$ & $\mathbf{2}$ & $\mathbf{3}$ & $\mathbf{4}$ & \\
\hline & & & & & & & \\
\hline
\end{tabular}

Keterangan :

- Skor 4 jika buku tersebut dapat memunculkan 3 aktivitas minimal siswa (mendengarkan, menulis, dan melihat) serta 3 atau lebih aktivitas lainnya

- Skor 3 jika buku tersebut dapat memunculkan 3 aktivitas minimal siswa (mendengarkan, menulis, dan melihat) serta 2 aktivitas lainnya

- Skor 2 jika buku tersebut dapat memunculkan 3 aktivitas minimal siswa (mendengarkan, menulis, dan melihat) serta 1 aktivitas lainnya

- Skor 1 jika buku tersebut hanya memunculkan 3 aktivitas minimal siswa (mendengarkan, menulis, dan melihat)

Jenis-jenis aktivitas siswa

- aktivitas mendengarkan contohnya mendengarkan.

- aktivitas menulis contohnya mengarang, menulis, menyalin.

- aktivitas melihat contohnya membaca, memperhatikan gambar, melihat video, demonstrasi, memperhatikan percobaan

- aktivitas lisan contohnya bertanya, memberikan saran, berpendapat, mengadakan wawancara, dan diskusi.

- aktivitas menggambar contohnya menggambar, membuat grafik, diagram, peta, atau denah.

- aktivitas gerak contohnya bermain, percobaan, membuat konstruksi, dan bermain peran.

- aktivitas mental contohnya menanggapi, mengingat, menganalisa, dan melihat hubungan. 
'Alia, Kukuh, Pengembangan Instrumen Analisis Buku...

Angket Kesesuaian Buku Tematik Terpadu Kurikulum 2013 Variabel Pendekatan Saintifik

Tabel 7. Angket Variabel Pendekatan Saintifik

\begin{tabular}{|c|c|c|c|c|c|c|c|}
\hline \multirow{2}{*}{ Tema } & \multirow{2}{*}{$\begin{array}{c}\text { Sub } \\
\text { Tema }\end{array}$} & \multirow{2}{*}{$\begin{array}{c}\text { Pembelajaran } \\
\text { ke- }\end{array}$} & \multicolumn{4}{|c|}{ Skor } & \multirow[t]{2}{*}{ Keterangan } \\
\hline & & & 1 & 2 & 3 & 4 & \\
\hline
\end{tabular}

Indikator pembelajaran saintifik:

- Skor 4 jika terdapat langkah pengamatan dan 4 langkah pendekatan saintifik lainnya (tidak perlu urut)

- Skor 3 jika terdapat langkah pengamatan dan 3 langkah pendekatan saintifik lainnya (tidak perlu urut)

- Skor 2 jika terdapat langkah pengamatan dan 2 langkah pendekatan saintifik lainnya (tidak perlu urut)

- Skor 1 jika terdapat langkah pengamatan dan 1 langkah pendekatan saintifik lainnya (tidak perlu urut)

Angket Kesesuaian Buku Tematik Terpadu Kurikulum 2013 Variabel Prinsip Buku Pelajaran yang Baik

1. Sub Variabel Prinsip Kelengkapan Sajian dan Relevansi

Tabel 8. Angket Sub Variabel Prinsip Kelengkapan Sajian dan Relevansi

\begin{tabular}{|c|c|c|c|c|c|c|c|}
\hline & Sub & Pembelajaran & & & & & Keterangan \\
\hline Tema & Tema & ke- & 1 & 2 & 3 & 4 & \\
\hline
\end{tabular}

Indikator prinsip kelengkapan sajian dan relevansi

- Skor 4 jika mencapai 4 kelengkapan sajian dan relevansi

- Skor 3 jika mencapai 3 kelengkapan sajian dan relevansi

- Skor 2 jika mencapai 2 kelengkapan sajian dan relevansi

- Skor 1 jika mencapai 1 kelengkapan sajian dan relevansi

Bentuk kelengkapan sajian

- Menyajikan kompetensi yang akan dikuasai siswa (KI, KD, indikator dan tujuan pembelajaran yang memuat kriteria $\mathrm{ABCD}$ ).

- Menyajikan manfaat dan pentingnya penguasaan kompetensi bagi kehidupan siswa (secara informatif maupun penemuan mandiri siswa berupa tugas). 
'Alia, Kukuh, Pengembangan Instrumen Analisis Buku...

Bentuk relevansi

- Penyajian materi sesuai dengan kompetensi yang harus dikuasai siswa.

- Penyajian tugas/soal/latihan sesuai dengan kompetensi yang harus dikuasai siswa.

2. Sub Variabel Prinsip Kaidah Bahasa

Tabel 9. Angket Sub Variabel Prinsip Kaidah Bahasa

\begin{tabular}{|c|c|c|c|c|c|c|c|}
\hline \multirow[b]{2}{*}{ Tema } & \multirow{2}{*}{$\begin{array}{c}\text { Sub } \\
\text { Tema }\end{array}$} & \multirow{2}{*}{$\begin{array}{c}\begin{array}{c}\text { Pembelajaran } \\
\text { ke- }\end{array} \\
\end{array}$} & \multicolumn{4}{|c|}{ Skor } & \multirow[t]{2}{*}{ Keterangan } \\
\hline & & & 1 & 2 & 3 & 4 & \\
\hline
\end{tabular}

Indikator prinsip kaidah bahasa

- Skor 4 jika tidak terdapat kesalahan kaidah bahasa

- Skor 3 jika terdapat 1 kaidah bahasa yang salah

- Skor 2 jika terdapat 2 kaidah bahasa yang salah

- Skor 1 jika terdapat 3 kaidah bahasa yang salah

Kaidah bahasa

- Penggunaan ejaan (pemakaian huruf, penulisan kata, penulisan unsur serapan, dan pemakaian tanda baca) sesuai dengan pedoman umum ejaan bahasa Indonesia yang disempurnakan

- Penggunaan istilah sesuai dengan penyempurnaan pedoman umum pembentukan istilah

- Struktur kalimat yang efektif

\section{SIMPULAN}

Berdasarkan hasil penelitian dan pembahasan dapat diambil simpulan sebagai berikut: (1) berdasarkan kajian teori, dirumuskan beberapa variable instrument adalah (1) variabel karakteristik pembelajaran terpadu, yang terdiri dari sub variabel holistik, bermakna, otentik, dan aktif, (2) variabel pendekatan saintifik, dan (3) variabel prinsip buku ajar yang baik, terdiri dari sub variabel kelengkapan sajian dan relevansi, serta sub variabel kesesuaian dengan kaidah Bahasa. Melalui metode pengembangan yang dilakukan dan di dalamnya termasuk kegiatan validasi ahli, disimpulkan bahwa instrument analisis buku tematik-terpadu pada kurikulum 2013 ini termasuk pada kategori yang valid dan dapat digunakan. 
'Alia, Kukuh, Pengembangan Instrumen Analisis Buku...

\section{DAFTAR RUJUKAN}

Akbar, S. 2013. Instrumen Perangkat Pembelajaran. Jakarta: Remaja Rosda Karya.

Akbar, S. 2013. Implementasi Pembelajaran Tematik Terpadu Berorientasi pada Pendidikan Karakter. Malang: Handout.

Arikunto, S. 2010. Prosedur Penelitian Suatu Pendekatan Praktik. Jakarta: Rineka Cipta.

Dahar, R. W. 1996. Teori-Teori Belajar. Jakarta: Erlangga.

Fogarty, R. 1991. How To Integrate the Curricula. USA: IRI/Sky Publishing

Inc, (Online), (http://books.google.co.id), diakses 16 Desember 2013.

Fogarty, R. 1991. Ten Ways To Integrated Curriculum.Educational Leadership, (Online), 49 (2): 61-65, (http://www.ascd.org), diakses 16 Desember 2013.

Hitipieuw, I. 2009. Belajar dan Pembelajaran. Malang: FIP Universitas Negeri Malang Mulyasa. 2013. Pengembangan dan Implementasi Kurikulum 2013. Bandung: PT. Remaja Rosdakarya Offset.

Permendikbud no 50 tahun 2015. Tentang Pedoman Umum Ejaan Bahasa Indonesia (PUEBI).

Putrayasa, I.B. 2010. Kalimat Efektif (Diksi, Struktur, dan Logika). Bandung: PT. Refika Aditama.

Sadirman, A.M. 2011. Interaksi dan Motivasi Belajar Mengajar. Jakarta: PT. Raja Grafindo Persada.

Sitepu, B.P. 2012. Penulisan Buku Teks Pelajaran. Bandung: PT. Remaja Rosdakarya Offset.

Smaldino, S. E. dkk. 2008. Instruksional Technology \& Media for Learning. Terjemahan Arif Rahman. 2011. Jakarta: Kencana Pranada Media Group

Sudio, R. 2013. Pendekatan Saintifik dalam Pembelajaran,(Online), (http://pembelajaranku.com), diakses 19 November 2013.

Sugiyono.2011. Metode Penelitian Kuantitatif Kualitatif dan R\&D. Bandung: Alfabeta. Tim Pengembang PGSD. 1996. Pembelajaran Terpadu D-II PGSD dan S-2 Pendidikan Dasar. Jakarta: Departemen Pendidikan dan KebudayaanDirektorat Jenderal Pendidikan Tinggi. 